\title{
Aniline Mustard
}

National Cancer Institute

\section{Source}

National Cancer Institute. Aniline Mustard. NCI Thesaurus. Code C249.

An alkylating mustard with antineoplastic activity. Aniline mustard forms covalent linkages

with nucleophilic centers, resulting in depurination, base miscoding and strand scission,

and crosslinking of DNA strands, all of which contribute to its cytotoxicity. (NCI04) 